\title{
THE TREATMENT OF PARAPLEGIA DUE TO FRACTURE- DISLOCATIONS OF THE DORSO-LUMBAR SPINE ${ }^{\star}$
}

\author{
By Dr. A. G. HARDy, M.B.E., M.A., B.M., F.R.C.S. \\ Spinal Injuries Unit, Sheffield, England
}

THIS paper concerns some aspects of the treatment of paraplegia due to bony injuries at the dorso-lumbar level of the spine with particular reference to observations on the results of management of the bony injury by conservative and operative régimes. The operative procedure has been the open reduction and internal fixation of displacements (figs. I and 2) as described by Holdsworth and Hardy (1953). The conservative procedure has been the control of existing displacements by the use of pillows in appropriate positions in bed.
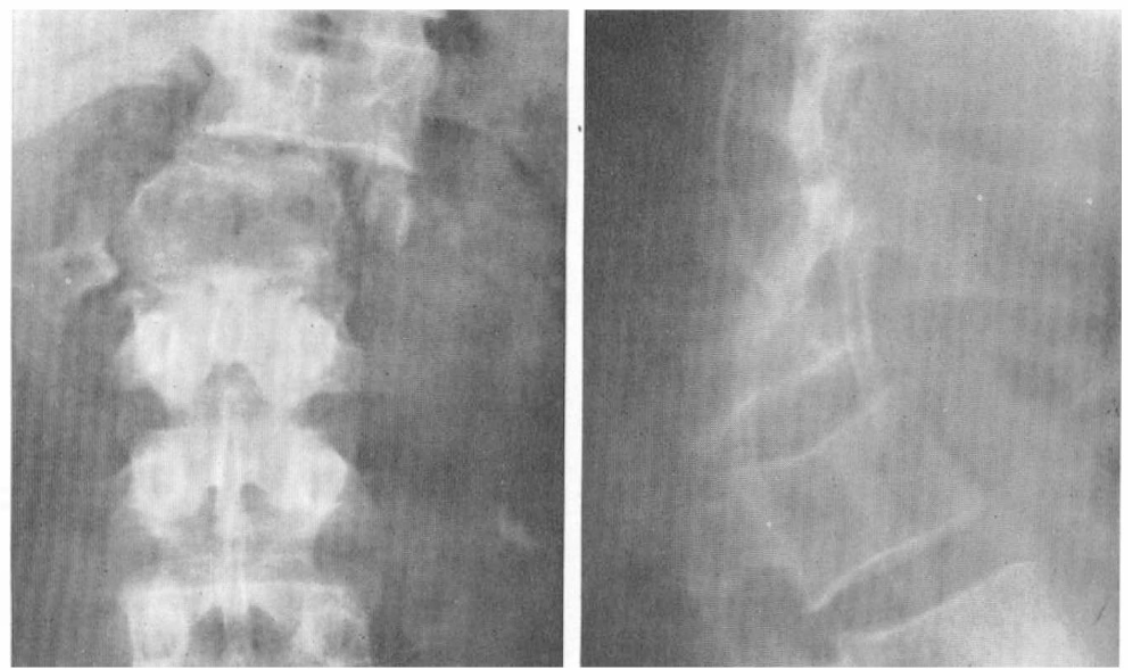

FIG. I

A.P. and lateral radiographs of a fracture dislocation of the I2th dorsal and Ist lumbar vertebrae.

The results are based on the experiences gained in the treatment of 156 patients of whom 6I had injuries at the D.V.I I/I2 level and 95 at the D.V.I2/L.V.I level. All the cases had the same routine of nursing management, the same routine of bladder and bowel control, as well as a similar programme of physical rehabilitation.

\section{Anatomical Considerations}

As pointed out in a previous publication (Holdsworth \& Hardy, 1953), the relationship of the spinal cord and its nerve roots to vertebral levels is important.

* Paper read at the 2 nd Scientific Meeting of the International Society of Paraplegia at Toyko on ro November I964. 

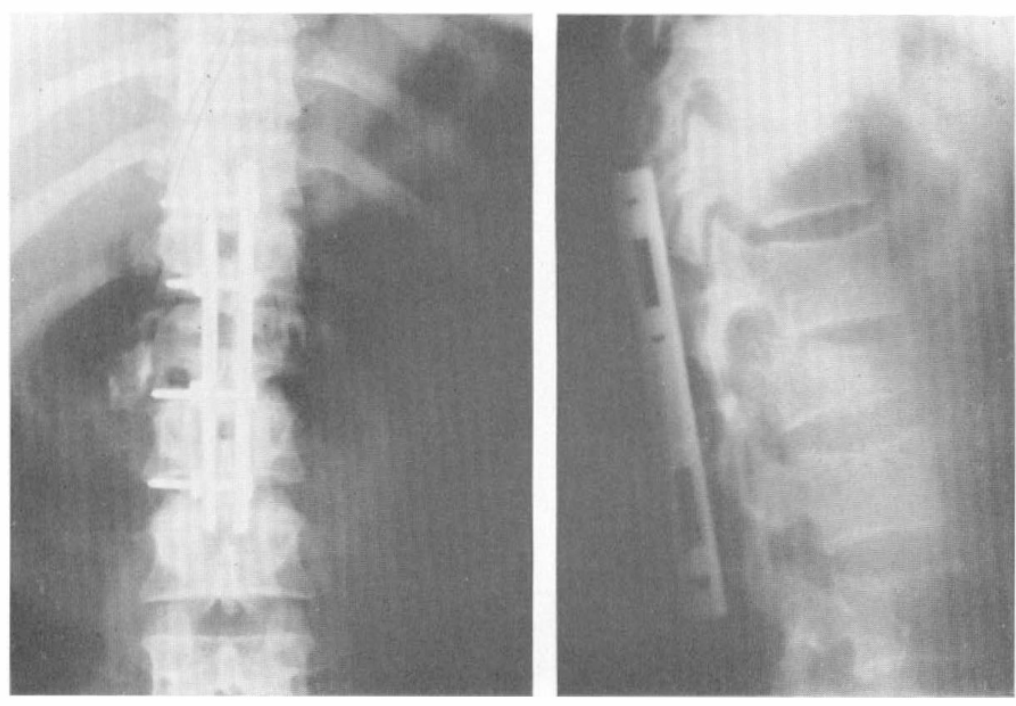

FIG. 2

Same case as figure I. A.P. and lateral radiographs after open reduction and internal fixation.

The spinal cord is generally considered to terminate at the level of the lower border of the first lumbar vertebra and Professor Parsons (I924) showed that the lumbar and sacral segments of the spinal cord lay between the level at the upper border of the tenth spinous process and a level at the upper border of the spinous process of the first lumbar vertebra (fig. 3). It should be noted that the obliquity of the nerve roots causes individual lumbar and sacral nerve roots to lie adjacent to the cord segments which are caudal to them and those which lie opposite the sacral segments included the whole of the lumbar and sacral nerve roots. Thus the lumbar and sacral segments of the spinal cord, together with their respective motor and sensory roots, are liable to be injured when displacements of the eleventh and twelfth dorsal or twelfth dorsal and first lumbar vertebrae occur.

\section{Neuropathological Observations}

Observations made at the time of surgical operations on the spine at the dorsolumbar level have shown variations in the severity of injury to cord and roots. These differences have also been demonstrated in histopathological sections on other cases (fig. 4). This section shows central spinal cord destruction whilst roots coursing from above are intact and well medullated although lying immediately adjacent to the damaged spinal cord.

Nerve roots can also survive in areas of even greater damage (fig. 5). In this section the sacral cord is seen to be almost entirely replaced by fibrous tissue through which pass a large number of intact and well medullated nerve roots although in somewhat irregular bundles.

Examination of the spinal cords of 20 cases of injury at the dorso-lumbar level has further confirmed the wide variation in level and extent of neurological des- 


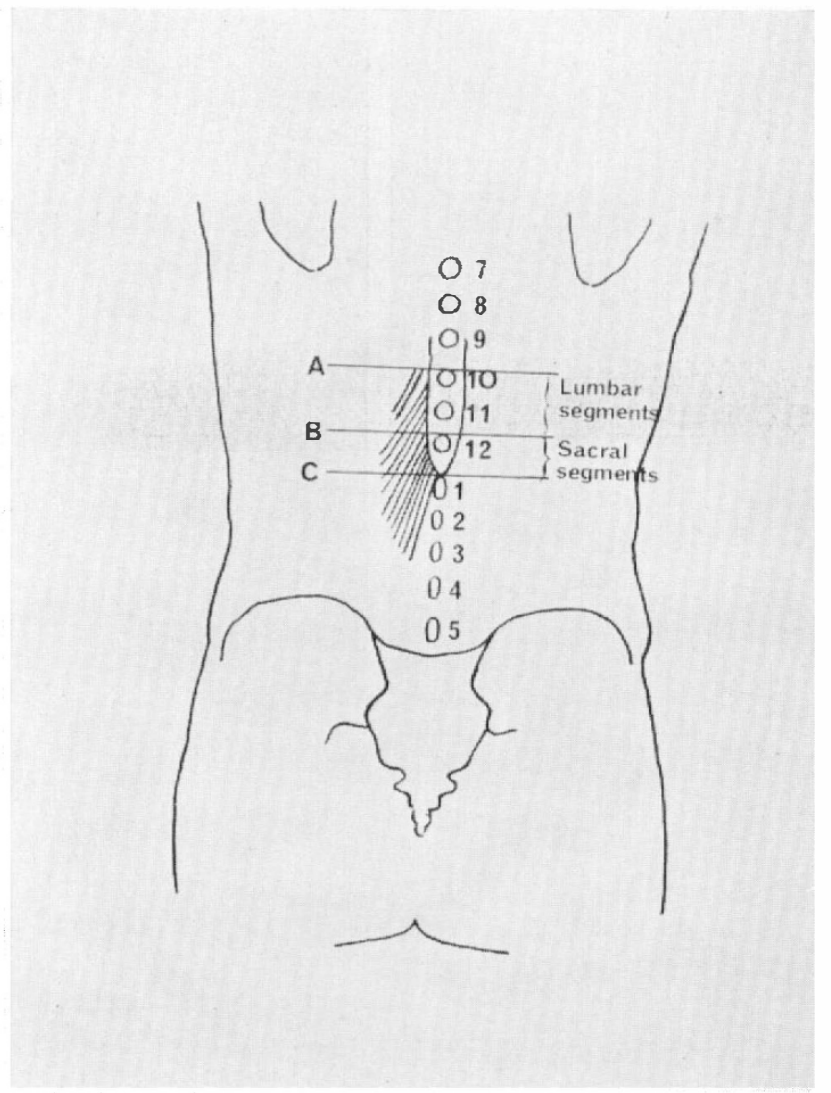

FIG. 3

A diagram to show relations of the lumbar and sacral segments of the spinal cord to the spinous processes of the overlying vertebrae (Parsons, I924).

truction (fig. 6). This is shown diagrammatically with areas of maximum damage shaded black and areas of damage of diminishing severity shaded with stippling.

These five examples were all cases of injury at the same bony level but with greatly differing clinical neurological features.

\section{MeChanism of Vertebral INJURIES}

Instability of the spine after fracture depends on the degree of damage to the posterior ligaments. If the posterior ligaments remain intact, then the forces of flexion violence are expended on the vertebral body and a typical crush fracture results. This is a stable situation and not commonly associated with paraplegia.

If, however, the posterior ligaments rupture with or without fractures of the articular processes, then an unstable condition can result. The common torsional flexion violence causes the posterior ligaments to rupture with fracture of one or both articular processes and allows the upper vertebrae to swing upon the lower. The intervertebral disc and a slice of the upper part of the lower vertebra is carried 


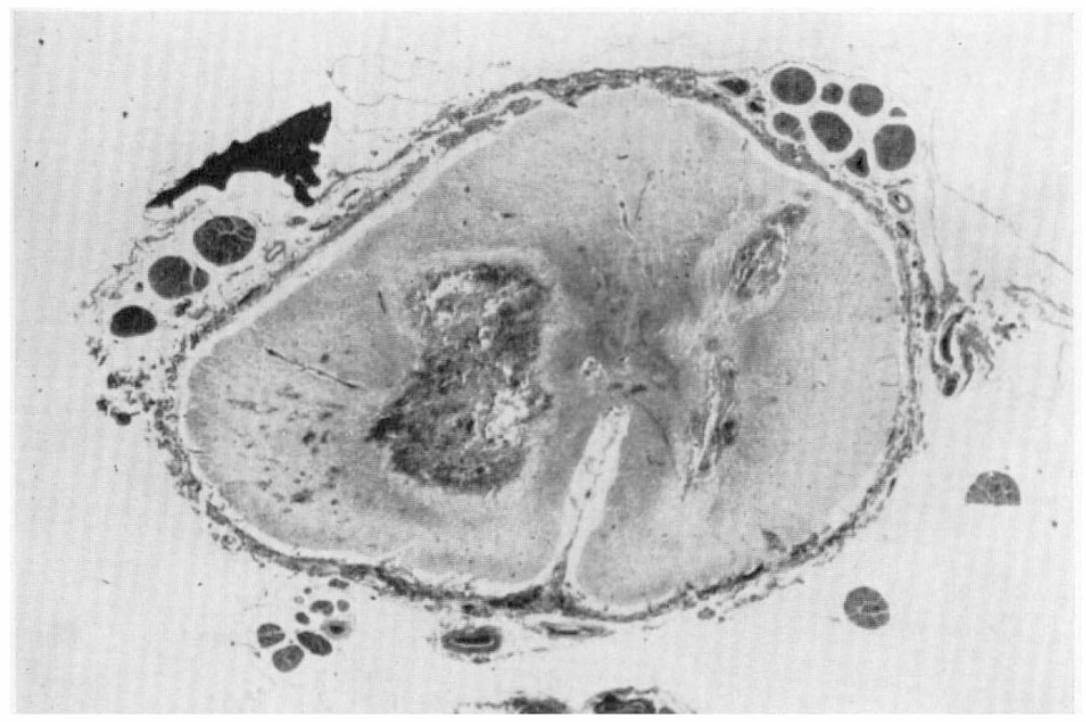

FIG. 4

Histological section of spinal cord showing intact nerve rootlets lying adjacent to an area of central spinal cord destruction.

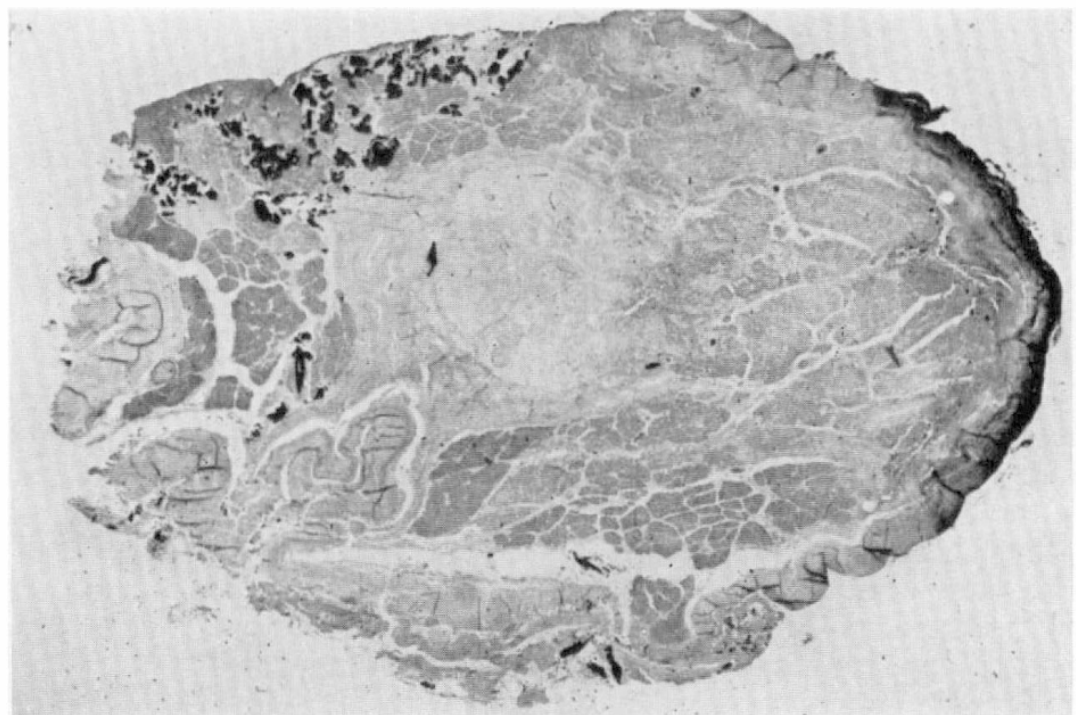

FIG. 5

Histological section of spinal cord showing medullated nerve rootlets in irregular bundles coursing through an area of gross spinal cord destruction and replacement gliosis. 


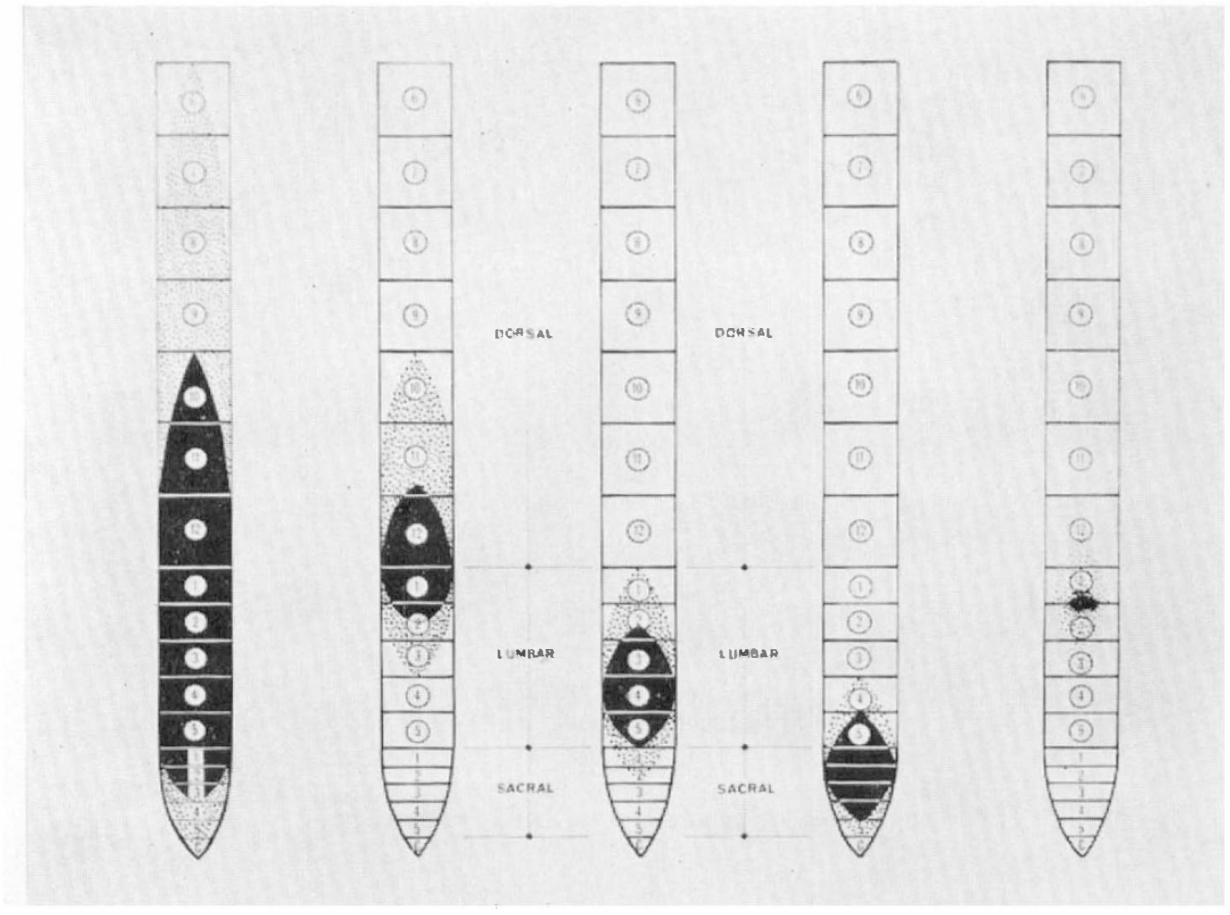

FIG. 6

Diagram showing the sites and extent of spinal cord damage in displacements at the dorsal I 2 and lumbar I bony level. Areas of maximal damage are shaded black and areas of lesser damage with black stippling.

with the upper vertebra. This fracture is unstable and is a common cause of spinal cord injury. There are all degrees of displacement from a slight shift to complete loss of alignment. It is to be noted that radiographs show only the position of the vertebrae in the resting phase after injury. They do not necessarily indicate the position of maximum displacement.

\section{TREATMENT}

The object of treatment of fracture dislocations of the spine is to restore and/or maintain alignment and stability in preparation for future weight-bearing, to facilitate natural recovery and to prevent complications arising in the paralysed parts of the body. Any method employed should promote the ease and safety of nursing management without risk to the patient.

With these objects in mind a large number of cases of traumatic paraplegia occurring at the dorso-lumbar level have received specific operative attention for the reduction and fixation of unstable fracture dislocations.

In the series under review there were 43 operations in 6I cases of injury at the D.V.II/D.V.I2 level and 77 operations in 95 cases of injury at the D.V.I2/L.V.I level.

The selection of cases for operation was on the grounds of clincial and radiological evidence of displacement with instability (figs. 7, 8 and 9). This was a 

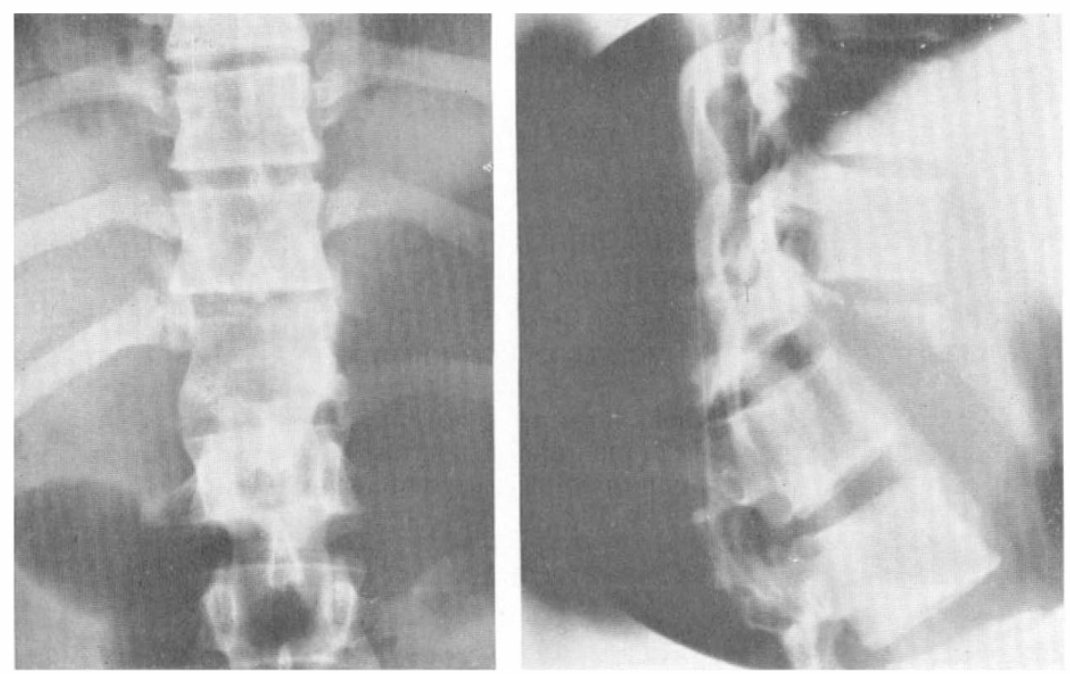

FIG. 7

Radiographs of an unstable fracture dislocation with gross displacement.
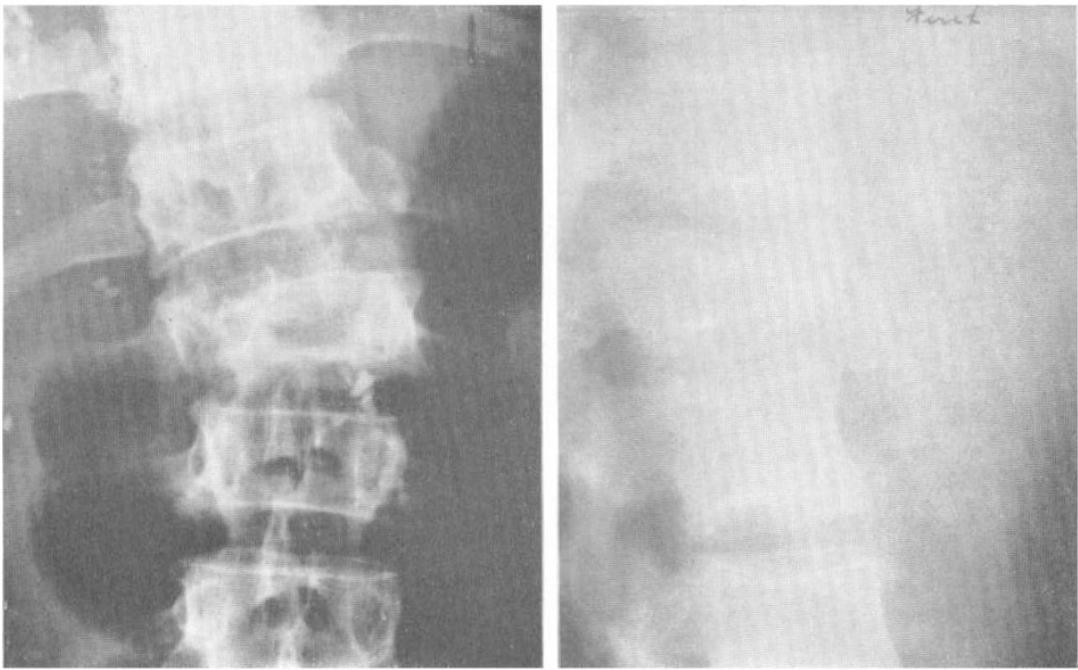

FIG. 8

Radiographs of an unstable fracture dislocation with minor displacement.

biased selection as the operative group of cases included those with the worst displacements whilst the conservative series tended to include those with relatively less evidence of instability. Thus one can only make observations on the two groups and true comparisons are not possible.

The nursing régime was the same for both groups of cases. The patient lay flat on the bed with the lumbar anatomical curve supported by a pillow. The routine was to lift, roll and turn the patient with the aid of the lumbar pillow and to 

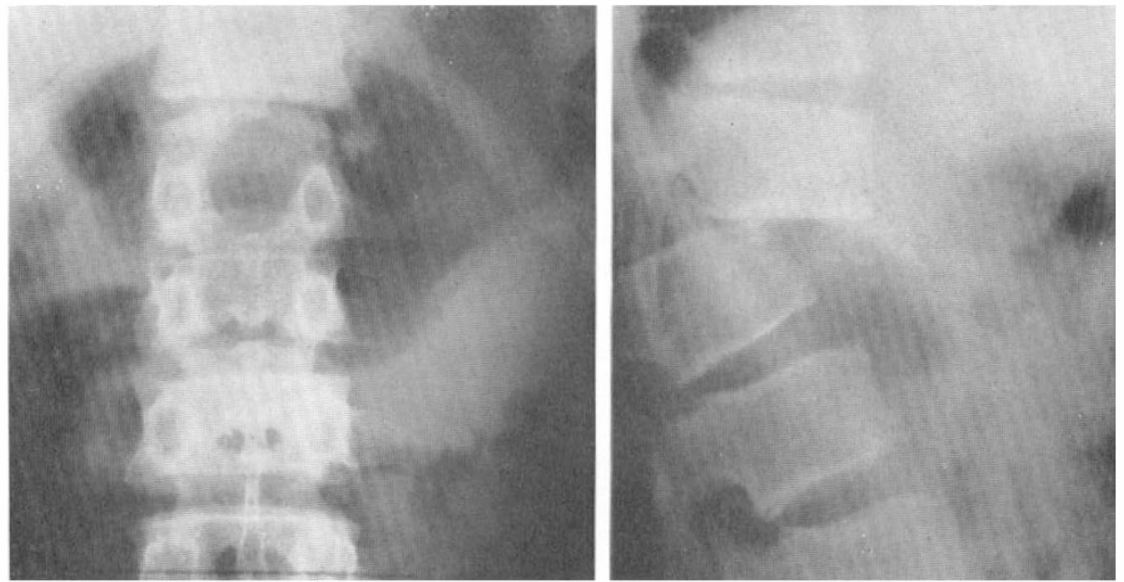

Fig. 9

Radiographs of an unstable fracture dislocation with moderate displacement

change the position two-hourly throughout the day and night. The first movement (fig. IO) was to lift the patient to the side of the bed. The second movement was to roll him on to his side using the lumbar pillow and with a nursing attendant supporting the uppermost lower limb (fig. I I). The third movement was to drop the pillow and inspect the pressure areas (fig. 12) before replacing the pillow and arranging other pillows to support the new position (fig. 13). A patient is thus turned from his right side on to his back and then to his left side at two-hourly intervals throughout the 24 hours.

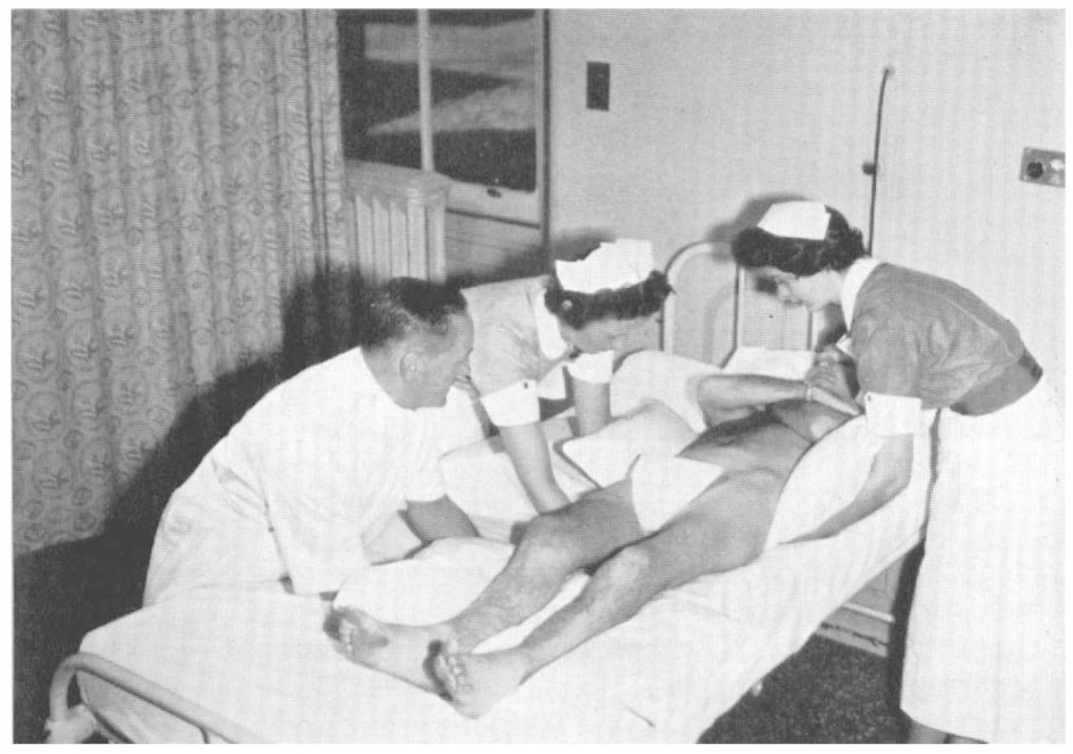

FIG. IO

Nursing Routine. First movement. Lift to side of bed. 


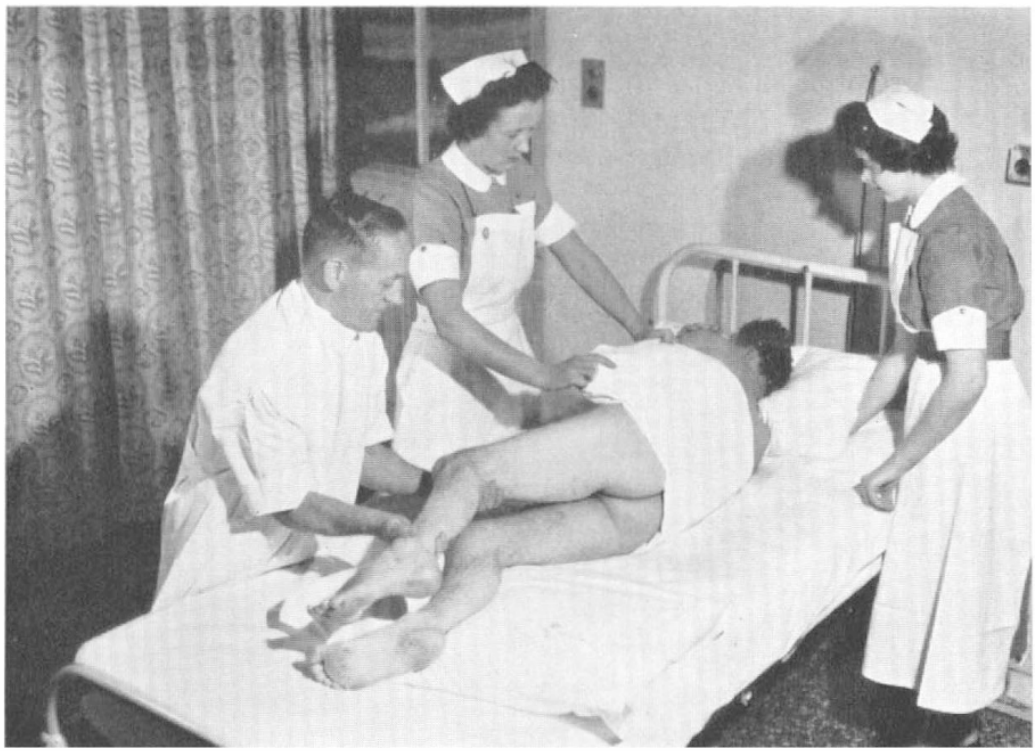

FIG. II

Nursing Routine. Second movement. Roll into the right lateral position.

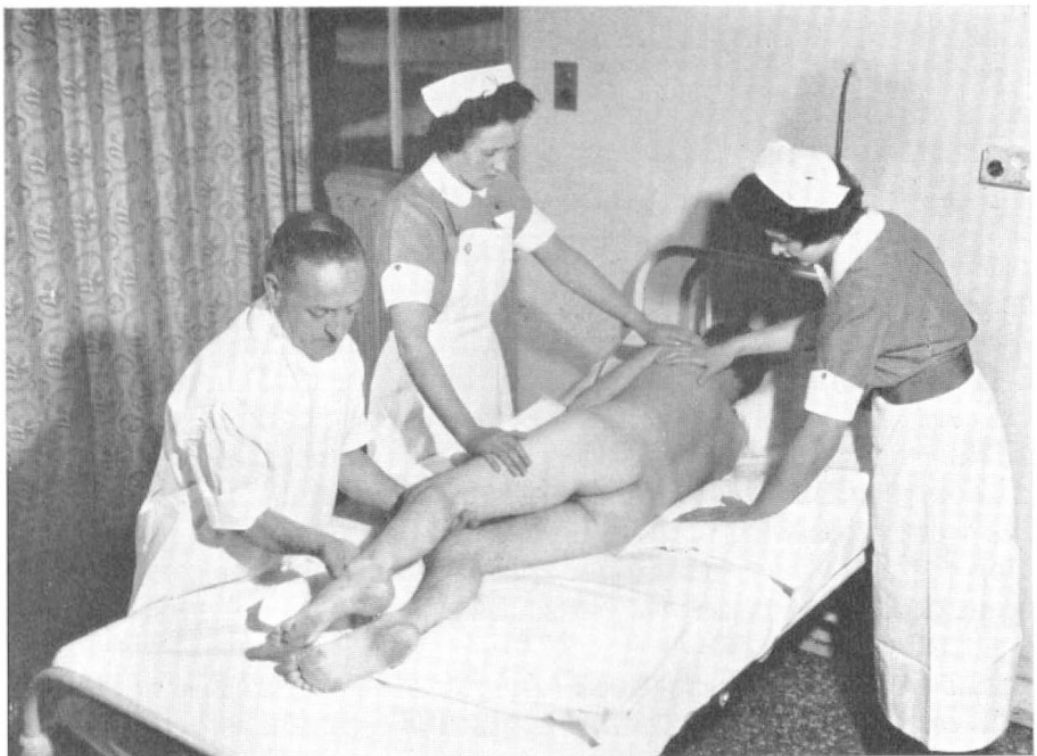

FIG. I2

Nursing Routine. Third movement. Skin inspection. 


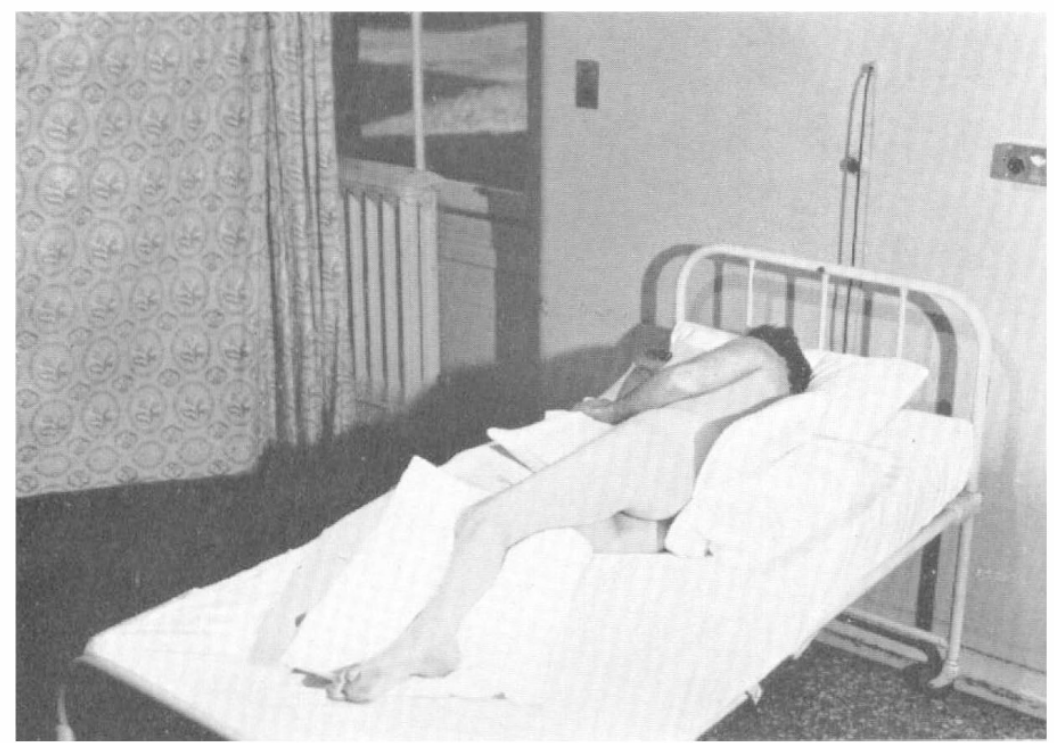

FIG. I3

Nursing Routine. Fourth movement. Supporting pillows.

\section{RESULTS}

The Spine. All the bony lesions eventually healed with solid stability but in a variety of positions. The operative groups of cases had the better positions, although some I 5 per cent. of them needed the removal of the fixation plates after bony healing had been achieved. Wound infection occurred in less than 2 per cent. of all cases.

The position of the spine in the non-operative groups was functionally satisfactory in the majority of cases but some needed operative removal of a prominent gibbus and a minority failed to acquire comfortable weight-bearing in the sitting and erect positions.

\section{THE NEUROLOGY}

Sacral Segmental Function. In the total series of I 56 cases there were only I9 who presented evidence of sensory sparing in the sacral segments at the time of initial examination. These 19 went on to achieve a voluntary type of bladder and bowel control. Of the remaining I37 cases, 94 acquired varying degrees of uncontrolled reflex activity in the lower sacral segments, while 43 remained completely without evidence of reflex activity in any form. The majority of these latter cases were those with bony injuries in the D.V.I2/L.V.I group. Operative intervention at the fracture site did not appear to influence the course of events and only two out of 120 operations were associated with a loss of sacral reflex activity.

Lumbar Segmental Function. Injuries at the Dorsal I I and I2 Bony Levels. Table I sets out the changes in lumbar segmental function associated with injuries at the D.V.I I/D.V.I2 level. There were 6I cases in this group of which 43 had had operative procedures at the fracture site. Neurological improvement was noted in I5. Twenty-eight showed no change and none were worse. 
TABLE I

Lumbar Segmental Function

Injuries at the Dorsal II and I2 Bony Level

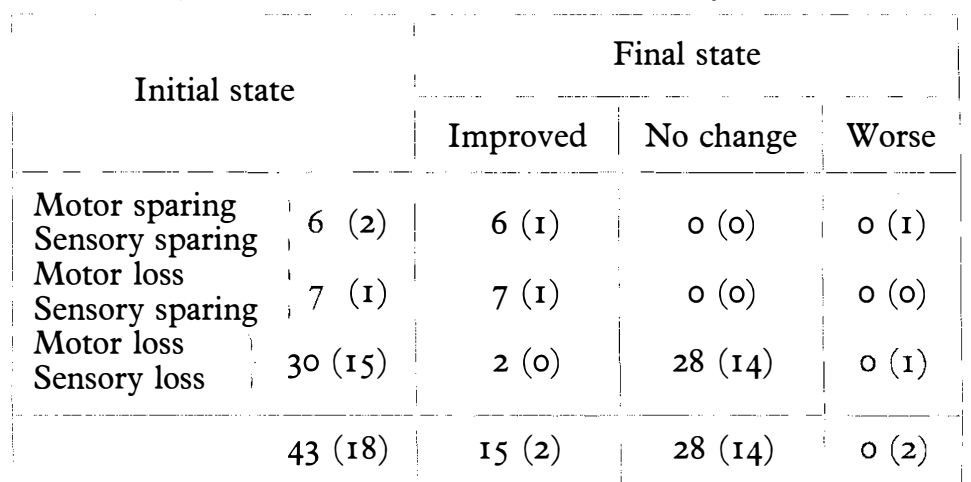

Table showing the changes in lumbar segmental function in the operative and nonoperative groups. Figures in parenthesis are those of the non-operative group.

In the non-operative group there were 18 cases of which two showed improvement, I4 no change and two were worse. The two deteriorations were in all probability due to progressive bony displacement arising from inadequate control of the bony lesion.

The cases in the operative group had a better initial neurological status than those in the non-operative group. This to some extent discounts the suggestion of better results associated with operation.

Injuries at the Dorsal I 2 and Lumbar I Bony Level. Table II sets out the changes in lumbar segmental function associated with injuries at the bony level of the I 2 th dorsal and ist lumbar vertebra (D.V.I2/L.V.I). There were 95 cases in this group,

TABLE II

Lumbar Segmental Function

Injuries at the Dorsal I 2 and Lumbar I Bony Level

\begin{tabular}{|c|c|c|c|c|}
\hline \multirow{2}{*}{\multicolumn{2}{|c|}{ Initial state }} & & inal state & \\
\hline & & Improved & No change & Worse \\
\hline $\begin{array}{l}\text { Motor sparing } \\
\text { Sensory sparing }\end{array}$ & I 8 (8) & I6 (8) & o (o) & $2(0)$ \\
\hline $\begin{array}{l}\text { Motor loss } \\
\text { Sensory sparing }\end{array}$ & $j 26(6)$ & I9 (6) & $5(0)$ & $2(0)$ \\
\hline $\begin{array}{l}\text { Motor loss } \\
\text { Sensory loss }\end{array}$ & j $33(4)$ & $4(0)$ & $29(4)$ & I (0) \\
\hline & $77(\mathrm{I} 8)$ & 39 (I4) & $34(4)$ & $5(0)$ \\
\hline
\end{tabular}

Table showing the changes in lumbar segmental function in the operative and nonoperative groups. Figures in parenthesis are those of the non-operative group. 
of which 77 had had operative procedures at the fracture site. Neurological improvement was noted in 39, 34 showed no change and four were worse.

In the non-operative group there were i8 cases, all of which had only minor degrees of bony displacement. Improvement occurred in I4, and four showed no change.

These observations fit the known facts as indicated in our neuropathological sections. Thus of the 95 patients with injuries at the D.V.I2/L.V.I level only 20 had a clear-cut sensory and motor loss at the level of the groins. In 23 patients the levels extended up on the abdominal wall, while in 52 there were levels in the lower limbs.

The cases showing most improvement were those with some sparing of activity in the initial instance. The speed and quality of recovery was inversely proportional to the time taken for any one new feature to appear.

It appears that the pattern of spinal cord damage at the D.V.II/I2 and D.V.I2/L.V.I levels is established at the time of the initial injury and is not substantially altered by either operative intervention or a conservative régime properly carried out.

The ease of handling of cases with big displacements treated by open reduction and internal fixation was definitely better than those treated conservatively but minor displacements can be managed by a careful nursing régime alone.

\section{SUMMARY}

This paper concerns the treatment of paraplegia due to bony injuries of the spine at the dorso-lumbar level. The observations made are based on the experiences gained in the early treatment of I 56 patients of whom 6I had had bony injuries at the D.V.II/I2 level and 95 at the D.V.r2/L.V.i level.

The anatomical relationships of the spinal cord and its nerve roots to the bony levels are detailed. The mechanism of the different types of fracture and fracturedislocation is outlined and shown to have a bearing on the type of spinal cord and root injury at the dorso-lumbar junction.

The importance of the nursing routine is emphasised and the method used at the Spinal Injuries Unit in Sheffield is described.

The patterns of neurological recovery are listed. The cases showing most recovery were those with the preservation of some sensory or motor activity from the time of the accident. The speed and quality of recovery was inversely proportional to the time taken for any one new feature to appear.

There was no great difference between the results in the operative and nonoperative groups of cases. True comparison of the two groups was not possible because of the biased selection of cases for each group. The non-operative group tended to include the cases with the lesser degrees of bony injury while the operative group included the major degrees of bony displacement and instability.

The ease of handling of this latter group of cases was greatly improved by the operative procedures.

\section{RÉSUMÉ}

Cette communication concerne le traitement de la paraplégie consécutiv à une atteinte traumatique de la colonne vertébrale au niveau de la région dorso-lombaire. Les observations faites sont basées sur l'expérience acquise dans le traitement à la phase aiguë de I 56 malades dont 6I avaient des fractures au niveau des I I et I 2 ème vertèbres dorsales et 
95 au niveau des vertèbres $D_{I} 2$ et $L_{I}$. Les relations anatomiques entre la moëlle épinière et ses racines par rapport à l'atteinte osseuse sont détaillées. Le mécanisme des différents types de fractures et fractures-dislocations est souligné et il est montré qu'il y a une relation sur le type d'atteinte médullaire et les racines à la jonction dorso-lombaire.

L'importance du nursing est démontré ainsi que les méthodes qui sont utilisées au Centre pour les lésions traumatiques de la moëlle épinière de SHEFFIELD.

Les différentes formes de récupération neurologique sont données. Les cas qui ont présenté une plus grande incidence de récupération sont ceux pour lesquels une préservation d'activité motrice ou sensorielle après l'accident fut diagnostiquée. La rapidité et la qualité de la récupération sont inversement proportionelles au temps pris pour que l'une ou l'autre activité apparaisse.

Il n'y a pas de grande différence entre les résultats des cas qui ont été opérés ou non; la vraie comparaison des 2 groupes n'était pas possible. Le groupe des malades non opérés tente à inclure les cas avec le moins de dégâts osseux, tandis que le groupe des malades opérés comprenait les plus grands déplacements et instabilités osseux.

La facilité de traitement de ce dernier groupe a été grandement améloirée par la chirurgie.

\section{ZUSAMMENFASSUNG}

Diese Arbeit betrifft die Behandlung der Paraplegie nach Knochenverletzungen der dorso-lumbalen Wirbelsäule. Grundlage unserer Beobachtungen sind die Erfahrungen in der Frühbehandlung von I 56 Pattenten (6I mit einer Fraktur oder Luxationsfraktur D. I I/I 2 , 95 in der Hohe von D.I2/L.I).

Die anatomischen Beziehungen zwischen Rückenmark, Nervenwurzeln und dem knöchernen Niveau werden beschrieben. Die Mechanik der verschiedenen Fraktur- und Luxations-Fraktur-Typen wird erörtert und es wird gezeigt, in welcher Weise sie zu besonderen Typen der Mark- und Wurzelverletzung in Beziehung stehen.

Der grosse Wert der Pflegemethoden wird hervorgehoben, und die im Sheffield Zentrum für Paraplegie geübte Technik beschrieben.

Typische Formen neurologischer Besserung werden angefürt. Weitgehende Besserung wurde in den Fällen gesehen, die von Anfang an inkomplett waren. Die Geschwindigkeit und Ausmass der Besserung standen in einen umgekehrten Verhältnis zu der Zeitspanne in der neue Zeichen nachweisbar wurden.

Resultate zeigten keinen wesentlichen Unterschied zwischen konservativ und operativ behandelten Fällen. Ein gültiger Vergleich zwischen den beiden Gruppen war nicht möglich, da die Auswahl für Operation selektiv war. Fälle mit geringerer knöcherner Verletzung wurden konservativ, mit schwererer Verletzung operativ behandelt. Operation machte die Pflege dieser letzteren Fälle mit Instabilität erheblich leichter.

\section{ACKNOWLEDGMENTS}

My thanks are due to Dr. Lionel Wolman, Consultant Neuropathologist to the United Sheffield Hospitals, for access to his work and interpretations on the neuropathology of the spinal cord sections and to the Editors of the Nursing Times and fournal of Bone and foint Surgery for permission to reproduce photographs already published.

\section{REFERENCES}

Hardy, A.G. \& Holdsworth, F. W. (1953). F. Bone ft. Surg. 35B, 540. Parsons, R. P. (1924). Spec. Rep. Ser. med. Res. Coun. (Lond.), No. 88. 